\section{A pesquisa no ensino de Geografia como possibilidade de diálogos trans e interdisciplinares}

Maíra Suertegaray Rossato *

Dirce Maria Antunes Suertegaray**

* Doutorado em Geografia pela Universidade Federal do Rio Grande do Sul (UFRGS). Professora no Colégio de Aplicação da UFRGS. exciplinares desenvolvidas no Projeto Amora, experiência de ensino desenvolvida na quinta e sexta séries do Ensino Fundamental no Colégio de Aplicação da Universidade Federal do Rio Grande do Sul (CAp/ UFRGS) em 2008. Duas propostas pedagógicas são descritas e analisadas, explicitando o significado de trans e interdisciplinaridade presentes em cada uma delas. Os mapas conceituais que resultaram dos projetos e os conceitos e/ou definições elaboradas através da oficina permitem avaliar o significado dessas práticas. Estas foram facilitadoras do aprendizado porque que resultam do interesse dos alunos e são geradoras de curiosidade e criatividade. Apresenta-se, então, uma possibilidade de ensino que associa a investigação e permite o trânsito disciplinar e uma interdisciplinaridade pensada como transversalidade, envolvendo professores e alunos em processos de interação e ambiente escolar mais dinâmico.

\section{Research in the teaching of Geography as a possibility of trans and interdisciplinary dialogue}

\begin{abstract}
This article is an analysis of educational practices in geography originated in the new ways of thinking about the process of teaching and learning. This approach is based on trans and interdisciplinary proposals developed in the Projeto Amora, teaching experience developed in the fifth and sixth grades of elementary school in Colégio de Aplicação da Universidade Federal do Rio Grande do Sul (CAp/UFRGS) in 2008. Two pedagogical proposals are described and analyzed, explaining the significance of trans and interdisciplinary present in each. The concept maps that resulted from the projects and the concepts or definitions developed by the workshop give meaning to these practices. These were facilitators of learning as arising from the students' interest and generate curiosity and creativity. It presents then a chance of education that combines research and allow the transit disciplinary and interdisciplinary thought of as a cross-cutting, involving teachers and students in processes of interaction and the school environment more dynamic.
\end{abstract}

** Doutorado em Geografia pela Universidade de São Paulo (USP). Professora no Departamento de Geografia da UFRGS.

\section{Key-Words:}

Teaching of Geography, trans and interdisciplinary, research projects,

elementary school.
Geografia Ensino \& Pesquisa, vol. 18, n. 2, maio/ago. 2014. 


\section{Introdução}

O ensino da Geografia tem, nas últimas décadas, passado por transformações significativas, particularmente no que se refere às novas propostas pedagógicas e também aos conteúdos dos livros didáticos. Contudo, poucas são as mudanças nas práticas educativas efetivas e na organização dos espaços escolares frente às possibilidades oferecidas pelo mundo nesta contemporaneidade.

Neste artigo, tem-se como objetivo analisar práticas educativas que derivam de novas formas de pensar o ensino, especialmente aquelas que centram a aprendizagem no aluno, ou seja, práticas em que o interesse pelo conhecimento provém do aluno mediado pelo professor. O enfoque para esta abordagem fundamenta-se em propostas trans e interdisciplinares, particularizadas no Projeto Amora, experiência de ensino desenvolvida na quinta e sexta séries do Ensino Fundamental de oito anos no Colégio de Aplicação da Universidade Federal do Rio Grande do Sul (CAp/UFRGS).

Estrutura-se este texto da seguinte forma: primeiramente apresentam-se os sentidos de trans e interdisciplinaridade veiculado nos Parâmetros Curriculares Nacionais (PCNs) em comparação com os significados destes para autores de diferentes áreas do conhecimento. Na continuidade, destaca-se o projeto que funda as experiências aqui relatadas - Projeto Amora. Neste contexto duas propostas pedagógicas serão descritas e analisadas buscando-se explicitar o significado de trans e interdisciplinaridade presentes em cada uma delas. Cabe dizer que, além disso, interessa também discutir, no âmbito das novas propostas, o papel da organização do espaço da escola que, segundo entendemos, de maneira geral carece de estruturação compatível com as novas formas de ensinar e aprender.

Mais especificamente, serão abordadas duas experiências de ensino: a oficina "Construindo a maquete do meu bairro", atividade de extensão do Departamento de Geografia em parceria com o CAp/UFRGS e a prática de projetos de investigação. Estas práticas compõem o conjunto de modalidades de ensino-aprendizagem que caracterizam a proposta do Projeto Amora e apresentam especificidades aqui reconhecidas como práticas trans ou interdisciplinares.

\section{Os sentidos de trans e interdisciplinaridade}

No contexto científico os conceitos de transdisciplinaridade e interdisciplinaridade têm sua maior divulgação a partir da segunda metade do século passado. Surgem como proposições que favorecem a construção do conhecimento de forma mais totalizante seja no campo científico, seja no âmbito do ensino. Os conceitos de transdisciplinaridade e interdisciplinaridade são múltiplos. Aqui não será feita uma apresentação exaustiva de tais conceitos. Indica-se inicialmente a presença dessas proposições no âmbito das propostas oficiais do ensino, a exemplo dos PCNs, e a partir deles é construído um pequeno diálogo com alguns autores que de forma diferenciada abordaram essas questões indicando, a perspectiva adotada nas experiências realizadas.

Tomando-se como referência os PCNs, em especial o volume de $5^{a}$ a $8^{a}$ séries do

Geografia Ensino \& Pesquisa, v. 18, n.2, p. $57-76$, maio/ago. 2014.

A pesquisa no ensino de Geografia como possibilidade de diálogos trans e interdisciplinares ensino fundamental para a disciplina Geografia observa-se uma proposta que enfatiza um ensino por grandes eixos temáticos e temas transversais. Além disso, é ressaltada a importância de trabalhar tomando como referência os conceitos geográficos. Entre esses conceitos são destacados os conceitos de lugar, paisagem, região, território, natureza.

Segundo esse documento, a proposição de eixos temáticos e temas transversais "baseia-se no reconhecimento da necessidade de incorporar tanto a idéia de flexibilização quanto a interdisciplinaridade no tratamento com o conteúdo dessa área”. (BRASIL, 1998, p.32). 
No mesmo documento acima citado, ao se referir aos conceitos geográficos é informado que: "ao pretender o estudo das paisagens, territórios, lugares e regiões, a geografia tem buscado um trabalho interdisciplinar, lançando mão de outras fontes de informações" (Ibidem, p.33). Indica-se aqui a busca de outras fontes como, literatura, cinema e imagens como práticas que conduziriam possivelmente a interdisciplinaridade.

No que se refere aos temas há também indicação nesse sentido quanto é afirmado: "estudar lugares, territórios, paisagens e regiões pressupõe lançar mão de uma ampla base de conhecimentos que não se restringem àqueles produzidos dentro do corpo teórico e metodológico apenas da Geografia. Muitas são as interfaces com outras ciências" (Ibidem, p.41)

Particularmente, quando trata do tema transversal Meio Ambiente a compreensão é bem definida admite-se nesse mesmo documento que a questão ambiental "pressupõe um trabalho interdisciplinar... não sendo possível abordá-la pela ótica de uma única ciência" (Ibidem, p.46).

Muito embora, os PCNs, apresentem essa proposição considera que não é oportuno discutir o significado desses dois conceitos. No entanto, é relevante, neste texto, uma breve decifração destes, pois dependendo da concepção que adotamos constituirá o resultado de nossas práticas.

A interdisciplinaridade, desde Piaget (1973) está relacionada com a superação da fragmentação científica. Este pesquisador buscava a superação dessa fragmentação através da interação entre as disciplinas sem, necessariamente, haver perda da identidade teórico-metodológica destas. Desta interação resultaria um conhecimento mais ampliado, sendo, por isso, mais complexo. Este nível de conhecimento é o que foi entendido por transdisciplinaridade. O sentido de transdisciplinaridade é aqui entendido como transcendência, ou seja, o que está além, no caso do conhecimento disciplinar.

Em texto divulgado pelo Instituto Paulo Freire (2009) é resgatado o sentido de transversalidade e transdisciplinaridade, além de indicar métodos pedagógicos que fundamentam o ensino-aprendizagem nessa perspectiva. No texto "Inter-transdisciplinaridade e transversalidade", disponível na página do página do Instituto, lê-se:

\footnotetext{
A transversalidade, bem como a transdisciplinaridade, é um princípio teórico do qual decorrem várias conseqüências práticas, tanto nas metodologias de ensino quanto na proposta curricular e pedagógica. A transversalidade aparece hoje como um princípio inovador nos sistemas de ensino de vários países. Contudo, a idéia não é tão nova. Ela remonta aos ideais pedagógicos do início do século, quando se falava em ensino global e do qual trataram famosos educadores, entre eles, os franceses Ovídio Decroly (1871-1932) e Celestin Freinet (1896-1966), os norte-americanos John Dewey (1852-1952) e William Kilpatrick (1871-1965) e os soviéticos Pier Blonsky (1884-1941) e Nadja Krupskaia (1869-1939).
}

O princípio da interdisciplinaridade na perspectiva divulgada por esse mesmo Instituto assume a concepção de transdisciplinaridade e transversalidade, visa superar o conceito de disciplina através do estabelecimento de conexões e construção de um objetivo ou tema comum. Nesse sentido tem-se a valoração da idéia de transcendência do conhecimento ou produção de novas leituras sobre um objeto ou tema. Trata-se na visão desse Instituto de superar o disciplinar no que se refere a seus interesses próprios. Entre as propostas metodológicas para essa superação é apontada a metodologia de Projetos.

O Método dos Projetos de Kilpatrick é nesse mesmo texto assim sistematizado: 
que consistia em os próprios alunos fazerem algo num ambiente natural, por exemplo, construindo uma casinha poderiam aprender geometria, desenho, cálculo, história natural etc. Kilpatrick classificou os projetos em quatro grupos: a) de produção, no qual se produzia algo; b) de consumo, no qual se aprendia a utilizar algo já produzido; c) para resolver um problema e d) para aperfeiçoar uma técnica. Quatro características concorriam para um bom projeto didático: a) uma atividade motivada por meio de uma conseqüente intenção; b) um plano de trabalho, de preferência manual; c) a que implica uma diversidade globalizada de ensino; d) num ambiente natural (INSTITUTO PAULO FREIRE, 2009).

Nos dois casos apontados observa-se a necessidade de transito disciplinar. Particularmente, o método de projeto, que centrado, por vezes no aluno individualmente, denota mais uma capacidade de transito disciplinar do que interdisciplinaridade como a concebemos.

As referências sobre transdisciplinaridade e interdisciplinaridade que trazemos a discussão e, fundamentam as práticas analisadas neste capítulo, expressam as idéias já expressas por Suertegaray (2003) onde a compreensão é de que a transdisciplinaridade significa, não somente o horizonte para além das disciplinas. Significa também a compreensão ampliada de sua disciplina, capacidade de transitar pelos diferentes campos do conhecimento, dialogar.

Posto desta forma pode se entender transdisciplinaridade mais como capacidade de transito disciplinar do que construção transcendente. Ou seja, sem negar a transcendência do conteúdo produzido pela conexão do conhecimento, aqui, o que queremos enfatizar é uma etapa para que se produza cada vez mais conhecimento complexo, no sentido exposto por Morin (1990) "o que é tecido junto". O que é denominado capacidade de transito disciplinar, significa para nós, colocar-se no lugar do outro, compreender suas formas de produzir conhecimento. Entende-se que só superando a nossa centralização disciplinar e nos colocando na fronteira de nosso campo de conhecimento ou disciplina escolar poderemos, construir práticas interdisciplinares. Em nosso entendimento transdisciplinaridade é um dos passos iniciais para a construção da interdisciplinaridade.

Em nosso ponto de vista, interdisciplinaridade constitui uma prática coletiva, surge da organização em grupo, hoje em rede, e tem como objetivo a busca da compreensão/ explicação de um problema formulado pelo conjunto dos investigadores ou, no caso da experiência aqui relatada entre professores/pesquisadores e alunos/pesquisadores.

$\mathrm{Na}$ escola, corresponderia a capacidade de colocar-se no lugar de outras disciplinas e outros saberes além dos saberes científicos e disciplinares, entendendo suas formas de construção e leitura do mundo, para a partir daí construírem-se as prática pedagógicas.

$\mathrm{Na}$ atualidade, a discussão se amplia e a transdisciplinaridade é entendida ainda mais amplamente. Leff (2001) acrescenta que o trânsito entre conhecimentos/saberes deve ultrapassar as disciplinas e ser ampliado através do diálogo com outras comunidades e saberes.

Geografia Ensino \& Pesquisa, v. 18, n.2, p. 57-76, maio/ago. 2014.

A pesquisa no ensino de Geografia como possibilidade de diálogos trans e interdisciplinares

\section{A proposição: o Projeto Amora}

Há uma dinâmica social que nos desafia, apresentando novos problemas, questiona a adequação de nossas antigas soluções e exige um posicionamento rápido e adequado ao cenário de transformações imposto pelas mudanças sociais, econômicas e tecnológicas com as quais nos deparamos nas últimas décadas. Este cenário permeia todas as esferas de nossa vida pessoal, mobilizando continuamente nossa reflexão acerca dos valores, atitudes e conhecimentos que pautam a vida em sociedade.

Ensinar exige coragem de ousar em atitudes que valorizem o educando como indivíduo repleto de experiências de vida, com curiosidade sobre o mundo em que vive, 
coragem está na postura coerente com a prática, na busca de novas metodologias, que não considerem o educando como um mero receptor de informação, mas como um sujeito que cria, que pode transformar (CASTROGIOVANNI et al., 2007)

Neste contexto, a pesquisa ganha um papel de destaque no processo educativo, em particular no repensar das práticas pedagógicas. Todo o conhecer é um processo de investigação e descoberta individual, porém sempre em relação ao outro. Parece ser impossível sermos professores sem sermos pesquisadores.

A postura do professor enquanto pesquisador é fundamental, uma vez que

[...] pesquisa significa compreender o mundo através de respostas que construímos sobre este mesmo mundo. Estas respostas são expressão da interação entre sujeitos e entre sujeitos e objetos. Pesquisar pressupõe conhecer o outro - o outro sujeito, o outro objeto. $\mathrm{O}$ ato de pesquisar é um ato de conhecimento, portanto, é parte do processo de educação (SUERTEGARAY, 2002,111).

Nesta ótica, o CAp/UFRGS constitui-se num referencial dentro da comunidade acadêmica no que diz respeito à pesquisa, implementação e o desenvolvimento de técnicas pedagógicas inovadoras.

$\mathrm{Na}$ contracorrente das transformações já referidas, o espaço da escola ainda resiste, mantendo um modelo tradicional de ensino, sobretudo no que se refere à abordagem disciplinar e aos seguintes aspectos organizacionais: partição do horário escolar em períodos fixos e independentes entre si; abordagem dos assuntos em seqüências estanques e compartimentadas eleitas exclusivamente pelos professores e de acordo com o previsto para cada série; cadernos e outras formas de registro ou acompanhamento das tarefas organizados por disciplina; avaliação de resultados também por disciplina, dentre outras.

Como conseqüência, esta forma de ver e viver a escola acarreta conseqüências nos processos que envolvem o conhecimento em si, acarretando o distanciamento entre a proposta escolar e o cotidiano dos alunos; a superposição e a não complementaridade de abordagens propostas nas diferentes disciplinas; a uniformidade de tratamento dos assuntos sem distinção entre turmas de uma mesma série e a tentativa implementação de um ritmo comum de aprendizagem entre alunos de um mesmo grupo. No que diz respeito aos aspectos que se referem ao envolvimento interacional professor/ aluno/conhecimento, percebem-se atitudes de desinteresse, não cooperação, trabalho individual, competição.

O Projeto Amora foi pensado a partir das necessidades contemporâneas, em especial as relativas ao ambiente escolar no que se refere as relações entre professores e entre estes e seus alunos e, no que se refere as concepções de espaço e tempo na construção do conhecimento na relação com as novas tecnologias

\footnotetext{
A amora é uma infrutescência formada por múltiplos frutos suculentos, derivados de uma reunião de flores diferentes que se desenvolveram próximas. Estes frutos são reunidos por um tecido também suculento, o que os transforma em uma estrutura única muito saborosa e, por isso mesmo, muito apreciada (DUTRA et al., 1999, p.4).
}

Tendo esta definição como inspiração, o Projeto Amora constitui-se em uma proposta curricular desenvolvida nas $5^{a}$ e $6^{a}$ séries do Ensino Fundamental do CAp e procura construir conhecimento a partir da interrelação entre as diferentes áreas do conhecimento, o que propicia a quem o constrói, uma visão ampla e interacional da realidade, também muito apreciada por integrar criativamente, afeto e cognição.

Desta forma, o currículo do Projeto Amora, pelas suas características de flexibilidade, possibilita a inclusão de metodologias e recursos pedagógicos diversos, favorecendo processos comunicativos, interativos e cooperativos ligados às novas tecnologias de informação e comunicação.

O projeto Amora surgiu como um projeto de pesquisa que tinha como principal ob-

Geografia Ensino \& Pesquisa, v. 18, n.2, p. 57-76, maio/ago. 2014.

Rossato, M. S.; Suertegaray, D. M. A. 
jetivo "constituir um campo de investigação pedagógica para a produção de conhecimentos e metodologias, por um processo de reestruturação curricular que incorpore as Novas Tecnologias de Informação e Comunicação (NTICs)" (DUTRA et al., 1999, p.9).

Metodologicamente, o caminho escolhido foi a pesquisa-ação emancipatória. Sua escolha como método deveu-se à possibilidade de exercício de uma postura de indagação como forma de apropriação e transformação ativa do conhecimento, postura essa considerada desejável, tanto do ponto de vista dos docentes como dos próprios alunos.

A pesquisa-ação emancipatória, tal como concebem Carr \& Kemmis (1988), é uma modalidade de pesquisa crítica, cuja essência é a participação e o processo coletivo de reflexão-ação. Trata-se, pois, de um processo sistemático de aprendizagem, que utiliza a crítica orientada para a ação, de forma que esta se converta em práxis, onde teoria e prática se ampliam, complementam e transformam (Ibidem, p.10).

A sistemática de trabalho em pesquisa-ação se desenvolve em ciclos de planejamento, ação, observação e reflexão, o que oportuniza aos participantes a teorização sobre as práticas, bem como a compreensão das relações entre as circunstâncias e a ação, através de dados, de análise e de argumentação desenvolvida, examinada e comprovada criticamente.

Nesta proposta pedagógica, a modificação do papel professor aparece na medida em que se prevêem funções relevantes, em interação: a do Professor Articulador, Professor Orientador, Professor Especialista e Professor Tutor (Ibidem, 1999). No desenvolvimento dos projetos de investigação, explicitados de forma mais detalhada adiante, destacam-se o Professor Orientador e o Professor Tutor, papéis normalmente exercidos concomitantemente e o Professor Especialista. Desta forma destacamos suas funções na Tabela 1.

Tabela 1 - Descrição das novas funções propostas pelo Projeto Amora para o Professor-Orientador, o ProfessorTutor e o Professor-Especialista.

\begin{tabular}{|c|c|c|}
\hline & PROFESSOR & \\
\hline $\begin{array}{l}\text { ORIENTADOR } \\
\text { * Orientador de projetos de } \\
\text { investigação quando estimula e } \\
\text { auxilia na viabilização de busca } \\
\text { e organização de informações, } \\
\text { frente às indagações do grupo } \\
\text { de alunos. } \\
\text { * Observador do processo de } \\
\text { construção do conhecimento } \\
\text { quando acompanha mais } \\
\text { diretamente um pequeno grupo } \\
\text { de alunos, entrevistando-os } \\
\text { sistematicamente, para registrar } \\
\text { a perspectiva do aluno sobre seu } \\
\text { próprio aprendizado. } \\
\text { * Professor especialista quando } \\
\text { reconhece a pertinência de } \\
\text { introduzir conceitos de seu } \\
\text { campo de conhecimento no } \\
\text { curso de um projeto } \\
\text { interdisciplinar, respeitando a } \\
\text { natureza e metodologias de seu } \\
\text { campo específico. } \\
\text { * Contato com especialistas em } \\
\text { diferentes campos do } \\
\text { conhecimento, sempre que for } \\
\text { pertinente ao seu papel de } \\
\text { orientador. }\end{array}$ & $\begin{array}{l}\text { TUTOR } \\
\text { * Acompanhar o processo de } \\
\text { aprendizagem de cada um dos } \\
\text { alunos sob sua responsabilidade } \\
\text { após distribuição definida pelo } \\
\text { grupo de professores. } \\
\text { * Propor-se-á compreender o } \\
\text { modo pelo qual os alunos estão } \\
\text { percebendo sua inserção nas } \\
\text { diferentes atividades, tendo em } \\
\text { vista as relações interpessoais e } \\
\text { a construção do conhecimento. } \\
\text { Este acompanhamento dar-se-á } \\
\text { de acordo com os critérios } \\
\text { comuns de avaliação } \\
\text { previamente estabelecidos com } \\
\text { o grupo de professores. } \\
\text { * Entrevistar os alunos } \\
\text { tutorados antes do momento } \\
\text { formal de avaliação (conselho } \\
\text { de classe). } \\
\text { * Elaborar o parecer dos alunos } \\
\text { tutorados para posterior análise } \\
\text { do grupo de professores no } \\
\text { conselho de classe. } \\
\text { * Compartilhar com o grupo de } \\
\text { professores as observações e } \\
\text { acompanhamentos junto aos } \\
\text { alunos tutorados. }\end{array}$ & $\begin{array}{l}\text { ESPECIALISTA } \\
\text { * Atuar como organizador de } \\
\text { situações de aprofundamento, } \\
\text { na sua área de conhecimento e } \\
\text { nas interfaces com as demais, } \\
\text { considerando os interesses } \\
\text { demandados a partir de projetos } \\
\text { e necessidades dos alunos, no } \\
\text { desenvolvimento dos conceitos } \\
\text { e habilidades específicas. } \\
\text { * Agir de forma descentrada } \\
\text { tendo em vista que sua atuação } \\
\text { não está mais restrita às } \\
\text { intervenções exclusivas de seu } \\
\text { próprio campo } \\
\text { conhecimento. }\end{array}$ \\
\hline
\end{tabular}


Na metodologia de projetos, destacamos as plataformas temáticas, entendidas no Projeto Amora como

proposições gerais, abrangentes e desafiadoras, ligadas aos temas do cotidiano e aos interesses dos alunos, a partir dos quais são desenvolvidos os projetos. Estas plataformas são organizadas pela equipe de professores e alunos, através de interesses e acordos estabelecidos entre eles (DUTRA et al., 1999, p.15).

O trabalho interdisciplinar é o eixo central do processo. Isso porque, neste momento, o papel de professor não é o de especialista e sim o de organizador das possíveis áreas de interesse e/ou necessidades dos aprendizes. Daí a importância de os momentos de estimulação e desafio serem os mais ricos e variados, possibilitando, aos alunos, um leque extenso de dados, fatos, imagens, experiências, sons, contato com pessoas e relações com o ambiente (atividades exploratórias). Assim, a plataforma temática definida pelos professores e alunos será ampla o suficiente para abranger projetos com múltiplas facetas.

Com vistas a definir os possíveis assuntos e interesses tanto dos projetos de investigação quanto na plataforma temática, há que se considerar os seguintes princípios: estudo das técnicas básicas de investigação; levantamento coletivo de aspectos considerados relevantes, atraentes ou curiosos durante as atividades exploratórias; formação dos grupos de investigação segundo interesses evidenciados; definição de um eixo comum de interesses.

Formados estes grupos, os quais dão origem aos projetos de investigação, é feita uma reunião com todos professores para que seja definido o eixo comum entre os interesses, formando as plataformas temáticas. Uma vez acordadas e constituídas as plataformas temáticas, as mesmas servem como deflagradoras de diversas frentes de trabalho que são selecionadas pelos alunos, de acordo com seus interesses e estágios de desenvolvimento, constituindo-se em projetos de investigação propriamente ditos.

Os projetos têm enfoques diferenciados e complementares, o que possibilita a exploração das plataformas temáticas sob múltiplas facetas. Desta maneira é propiciada uma seqüência de ações dinâmicas e interrelacionadas, sem as atuais demarcações provenientes da compartimentação de conhecimento e de horários.

Para o desenvolvimento dos projetos são criadas situações que oportunizam construção, integração, complementação e, principalmente, produção e conseqüente ampliação do conhecimento. Nestes momentos, diferentes grupos de alunos e professores estarão, simultaneamente, se dedicando a trabalhos e estudos diferenciados, construindo porções de conhecimentos que, ao serem socializadas, darão corpo e concretude às plataformas temáticas. Essa socialização se dá pelo fluxo dos conhecimentos nos diferentes momentos de aprendizagem (atividades especializadas e interdisciplinares, oficinas, assembléias, trabalhos de campo).

\footnotetext{
Trabalhos desta natureza, ao levarem em consideração a diversidade de características sócio-culturais, interesses, necessidades e ritmos dos estudantes envolvidos, estariam em consonância com a teoria das inteligências múltiplas de Gardner (1995), na medida em que buscam atender aos diferentes estilos cognitivos de aprender (Ibidem, p.16).
}

Os resultados e avanços relativos às ações já realizadas pelos diferentes grupos são discutidos por alunos e professores em assembléias gerais, oportunizando-se momentos de avaliação e planejamento das ações subseqüentes. Neste espaço, têm importância fundamental as trocas efetivadas entre todos os componentes do projeto, no sentido da abertura e visualização de novos caminhos para a investigação, bem como possibilidades para aprofundamentos.

Geografia Ensino \& Pesquisa, v. 18, n.2, p. 57-76, maio/ago. 2014.

Ao longo da trajetória de cada projeto serão considerados e analisados os diferentes caminhos percorridos pelos alunos para chegarem às soluções dos problemas propostos. Essa trajetória pode ser observada através do conjunto de registros, documentos, enfim, o acervo de 
informações que compõe o portfólio do aluno. Conforme Gardner (1994, p. 83-84), portfolio é a "coleção dos produtos acabados" que reflete a trajetória da aprendizagem do aluno, facilitando a reconstrução e a reelaboração desse processo (HERNANDEZ, 1997).

No decorrer do desenvolvimento dos projetos acontecem as atividades especializadas. Estas são atividades que derivam dos projetos e abrangem a construção de conhecimento específico dos diferentes campos. Tais atividades, planejadas e desenvolvidas, normalmente em grande grupo, são, inicialmente, interdisciplinares podendo, em algum momento, assumir caráter disciplinar.

$\mathrm{O}$ uso das novas tecnologias, principalmente às ligadas à Internet, abrem perspectivas inovadoras de interação entre pessoas e entre elas e os objetos de conhecimento, na medida em que se modificam os conceitos de espaço, tempo, hierarquia e inteligência. Grande parte da pesquisa dos alunos advém da internet, assim como o produto final da pesquisa, a página virtual, elaborada para ser divulgada eletronicamente.

As oficinas fazem parte das atividades do Projeto Amora e têm como objetivo desenvolver habilidades de pensamento. Não estão ligadas, necessariamente aos projetos de investigação dos alunos. Estas oficinas são formadas por grupos de, em média, 15 a 20 alunos, com diferentes estilos cognitivos e tempos de aprendizagem geralmente indicados pelo grupo de professores. Nela estes alunos desenvolvem atividades específicas, tais como produção textual, histórias em quadrinhos, culinária, jogos pedagógicos, etc.

De acordo com Vigotsky (1984), este tipo de abordagem favorece a ampliação da zona de desenvolvimento proximal, na medida em que é constituído um espaço de interação social como elemento determinante para o desenvolvimento e ampliação das potencialidades dos sujeitos.

$\mathrm{Na}$ criação das ofertas é possível, também, o trabalho interdisciplinar entre os professores da escola, o que enriquece ainda mais a proposta, na medida em que fomenta a troca entre colegas com experiências distintas e dá ao aluno múltiplas possibilidades de olhar sobre determinadas questões.

Nesta modalidade de trabalho, o aluno opta pela disciplina que deseja trabalhar; são feitas duas escolhas durante o ano letivo e, por isso, o desenrolar da disciplina acontece no período de um semestre. Por serem disciplinas de livre escolha, os grupos formados normalmente são pequenos e mistos, englobando alunos de $5^{a}$ e $6^{a}$ série, o que permite um trabalho mais próximo e mais focado para as necessidades e interesses do grupo.

O processo de avaliação abrange: a observação da aprendizagem em diferentes momentos; a oportunização de novos desafios com base na reflexão e busca teórica; o registro da produção dos alunos, com ênfase nos caminhos percorridos pelos mesmos; o diálogo freqüente e sistemático da equipe de trabalho; os encontros envolvendo as famílias, sempre que necessário. Assim, o acompanhamento e a avaliação deste processo de aprendizagem do aluno se dá em todas as situações oportunizadas pela escola, bem como pela valorização das vivências por ele trazidas.

Geografia Ensino \& Pesquisa, v. 18, n.2, p. 57-76, maio/ago. 2014.

A pesquisa no ensino de Geografia como possibilidade de diálogos trans e interdisciplinares

\begin{abstract}
A avaliação traduz-se numa reflexão continuada sobre "o que" o aluno pensa e "porque" ele, provavelmente, pensa desta forma; não é uma atividade pontual situada ao final de cada proposta de ensino. Trata-se de entender as potencialidades, os avanços e as singularidades de um modo ímpar de aprender: o da criança. Entende-se este aprender como próprio de cada sujeito, "através das devoluções dos alunos frente às indagações que eles mesmos se colocam e que tomam forma fundamentalmente quando trabalham em projetos de investigação. São evidências desta aprendizagem diferenciada a elaboração de certezas provisórias e dúvidas temporárias, a idéia do inacabamento no trato das questões e soluções, a veiculação da crítica reflexiva, a autonomia de trabalho, a busca permanente da interlocução, das trocas e da aceitação dos desafios, tanto cognitivos quanto nas relações interpessoais" (DUTRA et al., 1999, p.21).
\end{abstract}

O modelo pedagógico descrito anteriormente vem sendo concebido e experienciado segundo a metodologia da pesquisa-ação, que requer uma mudança no pensar o ensino-aprendizagem. Estas mudanças estão explicitadas nos procedimentos elencados na Tabela 2. 
Tabela 2-Procedimentos para a implantação da metodologia de Pesquisa-ação emancipatória.

\begin{tabular}{|c|c|c|}
\hline \multicolumn{3}{|c|}{ PROCEDIMENTOS } \\
\hline \multirow{4}{*}{$\begin{array}{l}\text { ESCOLA } \\
\text { Flexibilização dos horários em } \\
\text { classe, organizados de forma a } \\
\text { reunir professores e alunos em } \\
\text { trabalhos interdisciplinares. }\end{array}$} & PROFESSORES & ALUNOS \\
\hline & Trabalhos disciplinares à & Utilização do computador e dos \\
\hline & $\begin{array}{l}\text { medida das necessidades } \\
\text { demandadas pelos projetos. }\end{array}$ & $\begin{array}{l}\text { meios de comunicação } \\
\text { telemáticos nos ambientes de }\end{array}$ \\
\hline & sequências & acesso a diferentes fontes de \\
\hline $\begin{array}{l}\text { Reuniões semanais para } \\
\text { reflexão, ação e } \\
\text { planejamento de atividades } \\
\text { grandes e pequenos grupos. }\end{array}$ & $\begin{array}{l}\text { diferenciadas de conteúdos, sem } \\
\text { compromisso de atender às } \\
\text { tradicionais listagens previstas } \\
\text { em cada série. }\end{array}$ & $\begin{array}{l}\text { cultura, novas formas de } \\
\text { aprender e de partilhar } \\
\text { conhecimento. }\end{array}$ \\
\hline \multirow[t]{7}{*}{$\begin{array}{l}\text { Sessões semanais de estudos } \\
\text { interdisciplinares. }\end{array}$} & $\begin{array}{l}\text { Trabalho com redes conceituais } \\
\text { formadas a partir das } \\
\text { necessidades dos projetos. }\end{array}$ & $\begin{array}{l}\text { Realização de projetos } \\
\text { cooperativos dentro da mesma } \\
\text { turma, com turmas diferentes ou } \\
\text { grupos de outras escolas, via } \\
\text { Internet e correio eletrônico. }\end{array}$ \\
\hline & $\begin{array}{l}\text { Distribuição do tempo em sala } \\
\text { de aula em função dos projetos } \\
\text { bem como do desenvolvimento } \\
\text { das redes conceituais deles } \\
\text { oriundas, desmitificando assim a } \\
\text { hierarquização das disciplinas e } \\
\text { criando possibilidades de } \\
\text { trabalhos interdisciplinares. }\end{array}$ & \multirow{6}{*}{$\begin{array}{l}\text { Oportunidade de realizar } \\
\text { trabalhos em diferentes } \\
\text { ambientes de aprendizagem } \\
\text { (laboratórios, pátio, cinema, } \\
\text { teatro, bibliotecas, Internet, } \\
\text { outras escolas), rompendo com } \\
\text { a estrutura física tradicional de } \\
\text { sala, quadro e classes. } \\
\text { Participação em fóruns para } \\
\begin{array}{l}\text { apresentação dos trabalhos } \\
\text { desenvolvidos nos projetos de } \\
\text { investigação. }\end{array}\end{array}$} \\
\hline & Utilização de instrumentos de & \\
\hline & $\begin{array}{l}\text { da aprendizagem dos alunos ao } \\
\text { invés de testes e provas que } \\
\text { recortam um momento } \\
\text { específico da aprendizagem. }\end{array}$ & \\
\hline & $\begin{array}{l}\text { Produção de artigos científicos e } \\
\text { relatos de experiências. }\end{array}$ & \\
\hline & $\begin{array}{l}\text { Organização e participação em } \\
\text { seminários bimestrais para a } \\
\text { socialização dos conhecimentos } \\
\text { produzidos nos projetos. }\end{array}$ & \\
\hline & $\begin{array}{ll}\text { Organização de fóruns } & \text { dos } \\
\text { alunos para apresentação dos } \\
\text { trabalhos desenvolvidos } \\
\text { Projetos de Investigação. }\end{array}$ & \\
\hline
\end{tabular}

Fonte: DUTRA et al., 1999.

O Projeto Amora representa o trabalho desenvolvido por um grupo de professores em um espaço pedagógico de investigação pensado para tal, onde são desenvolvidas experiências interdisciplinares, mediante novos modelos de aprender e de ensinar.

Para Dutra et al. (1999, p.8) Não se trata mais de vencer grades programáticas, hoje irrelevantes frente a
magnitude do conhecimento acumulado pela humanidade, nem de desenvolver
ações centradas no professor, mas de combinar construção de conhecimento
significativo para eles com processos interoperativos, no sentido de favorecer
o desenvolvimento de suas inteligências, do auto-conhecimento e da atuação
social (HERNÁNDEZ \& VENTURA, 1998; SANTOMÉ, 1998).

O ensino por conteúdos parece não satisfazer mais. Precisamos trabalhar com questões que evoquem a prática, a realidade contextualizada do aluno, com suas necessidades, seus interesses, suas tensões. E mais, é preciso trabalharmos de forma coletiva, (inter)relacionada (CAS-
Geografia Ensino \& Pesquisa, v. 18, n.2, p. 57-76, maio/ago. 2014.

Rossato, M. S.; Suertegaray, D. M. A 
TROGIOVANNI et al., 2007). Na Geografia não deve ser diferente.

Abordagens atuais da Geografia têm buscado práticas pedagógicas que permitam colocar aos alunos as diferentes situações de vivência com os lugares, de modo que possam construir compreensões novas e mais complexas a seu respeito. Espera-se que, dessa forma, eles desenvolvam a capacidade de identificar e refletir sobre diferentes aspectos da realidade, compreendendo a relação sociedade/natureza. Essas práticas envolvem procedimentos de problematização, observação, registro, descrição, documentação, representação e pesquisa dos fenômenos sociais, culturais ou naturais que compõem a paisagem e o espaço geográfico, na busca e formulação de hipóteses e explicações das relações, permanências e transformações que aí se encontram em interação. Nessa perspectiva procura-se sempre a valorização da experiência do aluno.

É imprescindível o convívio do professor com o aluno em sala de aula, no momento em que pretender desenvolver algum pensamento crítico da realidade por meio da Geografia. É fundamental que a vivência do aluno seja valorizada e que ele possa perceber que a Geografia faz parte do seu cotidiano, trazendo para o interior da sala de aula, com a ajuda do professor, a sua experiência. Para tanto, o estudo da sociedade e da natureza deve ser realizado de forma interativa. No ensino, professores e alunos poderão procurar entender que tanto a sociedade como a natureza constituem os fundamentos com os quais paisagem, território, lugar e região são construídos. (PCNs 1998, p.30)

Para isso, o professor deverá criar situações concretas de aprendizagem, onde o educando possa analisar as relações espaciais, sociais, econômicas e políticas do seu cotidiano de forma mais crítica e participativa. Esta postura remete à idéia de coletividade, do significado dos nossos atos e das suas conseqüências, remete à idéia de responsabilidade social, ou seja, de um sujeito cidadão.

Desencadear os processos de compreensão do mundo, considerando o espaço produzido pelos homens ao longo de suas vidas é oportunizar aos alunos a capacidade de se entenderem sujeitos da sua história. E isto será possível se invertermos a equação dada pela escola tradicional que é "o professor passar o conhecimento, dando a aula", para a escola e a sala de aula como laboratório para investigar, para aprender a perguntar e para fazer perguntas significativas, no sentido de que levem a compreender o mundo da vida e não apenas identificar dados e fenômenos. Para saber fazer perguntas é necessário conhecimento que ao ser organizado gera novos questionamentos. A "educação geográfica" é um instrumento para a vida, que permite ler o novo mapa do mundo entendendo quais os fenômenos importantes e porque se apresentam assim. Tem início no começo da escolarização (já na Educação Infantil) e desenvolve-se ao longo dos vários anos do Ensino Fundamental e Médio.

\section{A experiência: o percurso e as práticas}

Geografia Ensino \& Pesquisa, v. 18, n.2, p. 57-76, maio/ago. 2014.

A pesquisa no ensino de Geografia como possibilidade de diálogos trans e interdisciplinares
As crianças chegam ao Projeto Amora com a expectativa de ingressar num sistema diferenciado, no qual a figura do professor unidocente deixa de existir, os horários são confeccionados semanalmente, as aulas são inter e disciplinares na forma de oficinas, assessorias e aulas especializadas e há o desenvolvimento dos projetos de investigação, que ao seu término são apresentados aos colegas e professores, avaliados e premiados. Os melhores projetos são escolhidos para serem reapresentados na seção "Vale a pena ver de novo" e inscritos no Salão UFRGS Jovem, o qual tem como objetivo apresentar os trabalhos de pesquisa desenvolvidos nas escolas.

\section{Orientação de projetos}

A experiência de orientação de projetos de investigação que será aqui relatada foi desenvolvida no ano de 2007 e dividiu-se em dois semestres. 
PUCRS, onde as crianças circularam livremente para experienciar todas as possibilidades oferecidas, tais como os experimentos interativos que buscam oferecer aos visitantes uma forma estimulante de conhecer os fenômenos naturais e as relações do homem com o mundo.

A partir desta visita e de outras intervenções posteriores feitas pelos professores para debater o papel do cientista, como e onde é o seu trabalho, os alunos responderam: O que eu quero saber? Por que en quero saber? Qual é a minha hipótese? e Como eu vou chegar a esta resposta? Através desta resposta, temos, de forma adaptada, o objetivo da sua pesquisa, a hipótese, a justificativa e a metodologia.

Com este material, o grupo de professores definiu as plataformas temáticas, os professores responsáveis por elas e os seus alunos orientandos. A partir daí o trabalho passou a ser desenvolvido em pequenos grupos, em diferentes ambientes da escola, como biblioteca, sala de informática e laboratórios. O professor orientador, agora com seus orientandos, tinha o papel de iniciar questionamentos para que o aluno "lapide" aquela folha inicial de idéias.

Os alunos com projetos inseridos nas plataformas temáticas "Meio Ambiente" (Primeiro semestre 2007) e "Geografia" (Segundo semestre 2007), sob orientação da professora Maíra Suertegaray Rossato, ao final do processo tinham as seguintes questões a serem respondidas:

- Primeiro semestre:

O que é Aquecimento Global?

O que causou a morte dos peixes do Rio dos Sinos?

Será que a água potável vai acabar?

Por que a Amazônia está sendo destruída?

Quais os benefícios que a Amazônia traz para o Brasil?

O que é reciclagem?

- Segundo semestre:

$\square$ Como acontecem os "super desastres" (naturais) relacionados às placas tectônicas?

$\square$ Por que somem muitas embarcações no Triângulo das Bermudas?

Qual a história dos principais desastres naturais envolvendo vulcões e terremotos?

O que é o Grand Canyon e como ele foi formado?

Como é o Grand Canyon?

Como surgiu o Grand Canyon e por que ele tem esse nome?

$\square$ Qual o lugar mais preservado do Brasil por lei? Como ele é?

Durante o desenvolvimento dos projetos, as crianças pesquisavam autonomamente, trazendo informações que julgavam pertinentes, mas também produziam a partir de materiais levado pela orientadora, como filmes, livros, recortes de jornais ou revistas. É muito importante mostrar aos alunos a importância da autoria, chamando a atenção para o cuidado com a apropriação indevida de textos da internet, entre outros, sem citação de fonte de consulta. Trabalhamos muito com a idéia da reescritura, ou seja, o aluno lê o texto original e escreve com suas palavras a síntese do que o autor quis dizer e a partir daí ele vai montando o seu próprio texto.

Ao mesmo tempo em que lê e escreve, o aluno-pesquisador já inicia a confecção da sua página eletrônica. Para esta elaboração a criança tem liberdade de definir a forma e o conteúdo da sua página (cores, fontes, figuras, textos, disposição e número de links a serem inseridos), respeitando as combinações feitas em aula, como por exemplo, inserir a fontes consultadas, utilizar linguagem adequada aos trabalhos de escola etc.

A plataforma utilizada para a elaboração das páginas permite a edição das mesmas on line, podendo, portanto, ser acessada e complementada em casa. Para isso são definidas senhas que só podem ser utilizadas pelo grupo de alunos responsáveis pela página e pela professora orientadora. Esta ferramenta permite, ainda, que a professora deixe questionamentos, recomendações e sugestões nas páginas dos alunos para que eles modifiquem ou corrijam o que está inadequado.

Geografia Ensino \& Pesquisa, v. 18, n.2, p. 57-76, maio/ago. 2014.

Rossato, M. S.; Suertegaray, D. M. A. 
As três páginas eletrônicas a seguir constituem os resultados das duas edições dos projetos de investigação do ano de 2007. Elas podem ser acessadas através dos endereços:

$\square$ http://amorameioambiente.pbworks.com/

http://amorageografiadaterra.pbworks.com/

http://amoragrandcanyon.pbworks.com/

Como foi explicado no item anterior, são organizados fóruns para apresentação dos trabalhos. Nestas apresentações as crianças mostram as páginas elaboradas, apresentam seus resultados e respondem aos questionamentos dos colegas e professores. Os alunos aguardam com ansiedade este momento e planejam com cuidado a apresentação, pois para eles é muito importante que o trabalho seja bem avaliado e eles possam reapresentá-lo para colegas de outras séries ou mesmo crianças e professores de outras escolas.

Serão apresentados aqui dois resultados produzidos pelos alunos em suas pesquisas. O primeiro evidencia a criação e o desenvolvimento de etapas metodológicas próprias a partir das necessidades que se apresentaram durante o trabalho uma vez que o objetivo da aluna era algo que não poderia ser encontrado e extraído diretamente de pesquisa bibliográfica. O segundo representa a construção de uma aluna que inicialmente apresentou muitas dificuldades para se concentrar e se organizar de forma a produzir de forma autônoma. No decorrer da atividade, a partir da orientação, leitura e exercício da produção textual, observou-se uma mudança de comportamento que culminou em uma apresentação clara e bastante segura de seus resultados. Os mapas conceituais explicitam o processo construtivo que se desenvolveu ao longo da orientação dos projetos, indicando uma aprendizagem bastante significativa, uma vez que partir de suas curiosidades, seus interesses.

Em seu projeto de pesquisa, a aluna V. queria responder a seguinte pergunta: Qual o lugar mais preservado do Brasil por lei? Como ele é? A hipótese para sua pergunta era que este lugar seria Fernando de Noronha. Na página eletrônica construída por ele descreveu sua metodologia da seguinte forma:

Geografia Ensino \& Pesquisa, v. 18, n.2, p. 57-76, maio/ago. 2014.

A pesquisa no ensino de Geografia como possibilidade de diálogos trans e interdisciplinares
Como eu não iria encontrar minhas respostas facilmente em livros, criei, com ajuda da minha tutora, minha própria metodologia. Eu vi, no início do projeto, que na lei ambiental brasileira existem dois grupos de unidades de conservação (UCs): as unidades de uso sustentável, que permitem que as pessoas retirem alimentos, água e plantas do lugar; e as unidades de proteção integral, que permitem a visitação para a realização de pesquisas cientificas, atividades de educação ambiental, recreação e lazer.

Eu escolhi a unidade de proteção integral, porque, nas unidades de uso sustentável, as pessoas poderiam retirar coisas do lugar para se sustentar, desta forma, tirando as coisas de lá, o local não estaria totalmente protegido.

Nas unidades de proteção integral existem 5 tipos diferentes de UCs, algumas podem receber visitas, outras são só para estudos, e outras não se pode entrar nem para estudo. Dentre essas UCs, tem a estação ecológica, a reserva biológica, o parque nacional, o monumento natural e o refúgio da vida silvestre.

A unidade que eu escolhi entre essas foi à reserva biológica porque não se permite nenhum tipo de visitas, então é mais preservado. Para descobrir e selecionar as reservas biológicas mais preservadas eu olhei os mapas da vegetação original e da vegetação atual, das estradas, das áreas com coleta de lixo, das áreas indígenas. Tudo isto para ver qual reserva tem o ambiente mais preservado.

Depois de analisar esses mapas cheguei a três reservas, a reserva de Uatumã, a do Rio Trombetas e a de Abufari.

Mas como teria que chegar na mais preservada, tive que criar novos critérios para o descarte, como a ocorrência de queimadas, de desmatamentos, de caças ou de pesca ilegal no lugar.

Em seus resultados V. colocou que

A maioria das Reservas Biológicas fica do lado leste do Brasil nos estados litorâneos, mas acredito que as reservas que estão mais preservados são Uatumã, Rio Trombetas e Abufari que ficam no Pará e na Amazônia e protegem a Floresta Amazônica.

(...) a reserva biológica de Uatumã foi construída para diminuir os efeitos da criação da usina hidroelétrica de Balbina, que foi criada bem onde as tartarugas 
faziam as desovas. Então essa reserva não podia ser a mais preservada porque a praia não é natural, é construída pelo homem.

(...) a reserva biológica do Rio Trombetas não é a mais protegida porque atualmente existem muitos posseiros na região que, além de pescarem e caçarem, praticam atividades agrícolas ilegalmente.

(...) a reserva biológica de Abufari protege muitas espécies de tartarugas, de peixes, de aves e de plantas. As tartarugas quase desaparaceram (entraram em extinção) por causa da caça para venda. Essa reserva foi criada para cuidar dos quelônios (...). Eles protegeram estes animais, porque esse local é considerado o maior tabuleiro de desova da Amazônia, e estava havendo retirada dos ovos e caça ilegal dos quelônios.

A aluna V. mostrou-se muito autônoma em sua pesquisa e bastante interessada nas suas descobertas. Seus mapas conceituais evidenciam seu a aprendizado (Figuras 1 e 2).

Figura 1 - Primeiro mapa conceitual da aluna V. elaborado no inicio da sua investigação.

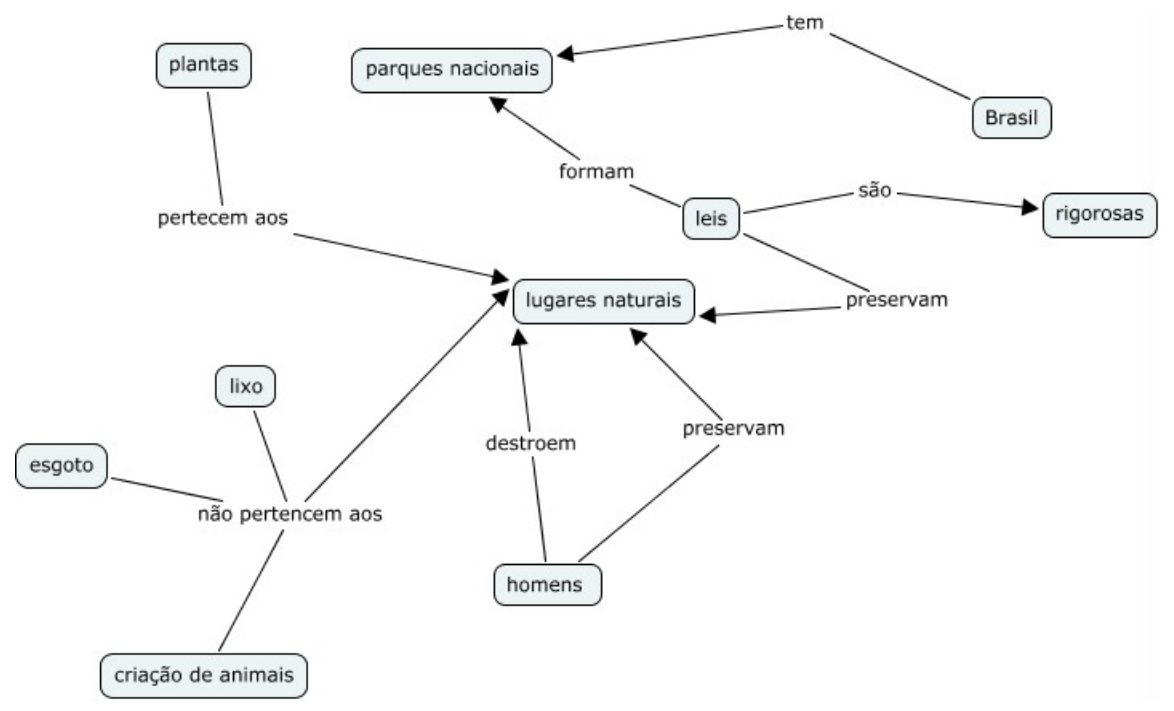

Fonte: arquivo pessoal das autoras.

Figura 2-Segundo mapa conceitual da aluna V. elaborado no final da sua investigação.

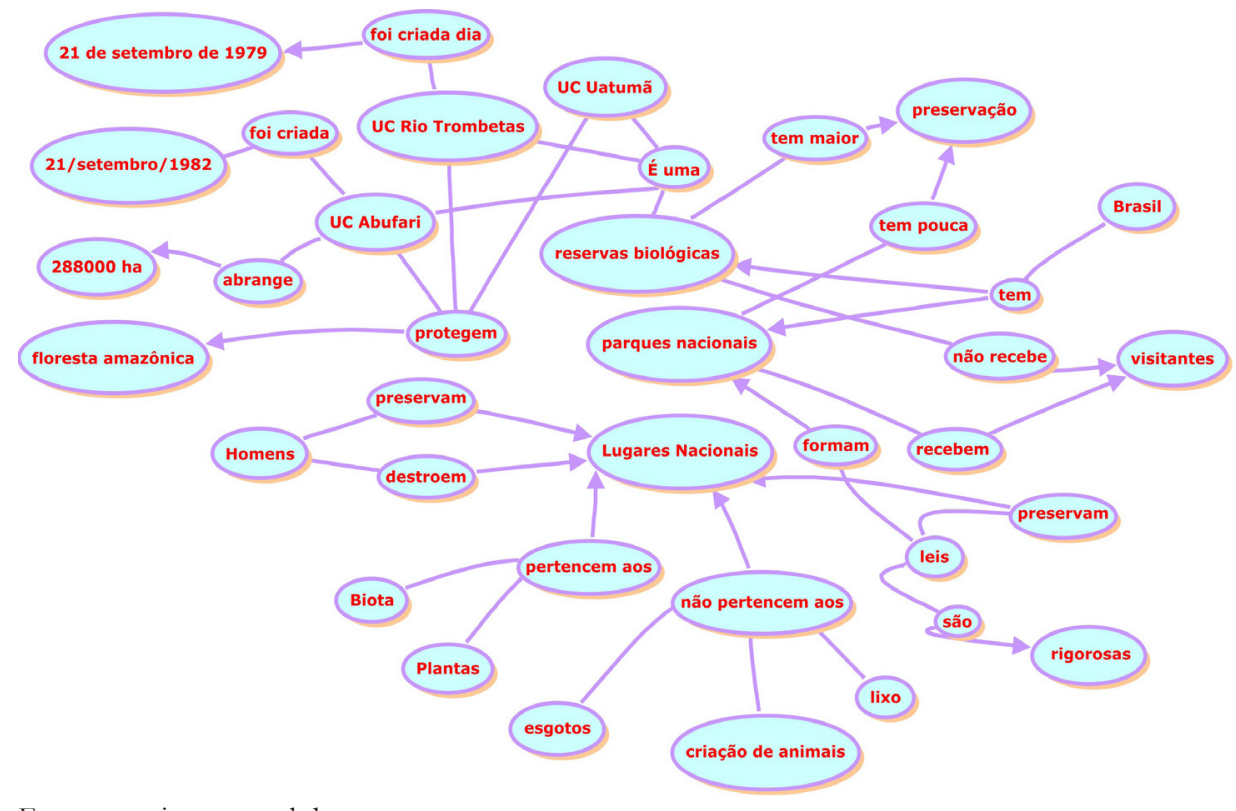

Geografia Ensino \& Pesquisa, v. 18, n.2, p. 57-76, maio/ago. 2014. 
A pergunta a ser respondida pela aluna J. era: Qual a história dos principais desastres naturais envolvendo vulcões e terremotos? Sua hipótese era a seguinte: "Os desastres naturais aconteceram por causa das placas tectônicas que se chocam e por isso muitas pessoas morreram. Os vulcões entraram em erupção e soltam lava matando muitas pessoas e atingindo muitas casas. Os terremotos destruíram muitas casas".

Com um procedimento metodológico baseado na pesquisa bibliográfica, J. precisou definir o que entendia por MAIOR terremoto e MAIOR vulcão para dar continuidade ao trabalho.

Para descobrir qual foi o maior terremoto e o maior vulcão da história, eu considerei o número de pessoas que morreram e as casas destruídas. Eu descobri que o maior terremoto, aquele que matou mais pessoas e destruiu mais casas foi o que ocorreu no oceano Índico no ano de 2004. O vulcão que mais matou mais gente foi o vulcão Tambora no ano de 1815.

Embora pareça uma elaboração bastante simples, J. apresentou uma melhoria significativa de seu desenvolvimento cognitivo e de sua construção conceitual, o que fica bastante evidente nos seus mapas conceituais (Figuras 3 e 4).

Figura 3-Primeiro mapa conceitual da aluna V. elaborado no inicio da sua investigação.

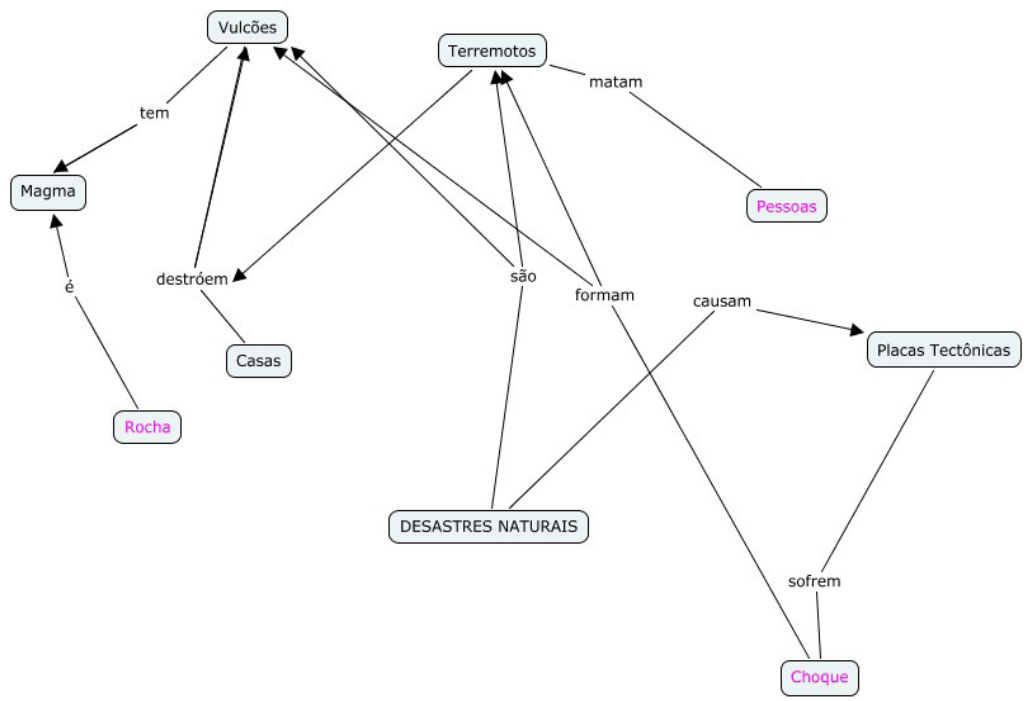

Fonte: arquivo pessoal das autoras.

Figura 4-Primeiro mapa conceitual da aluna V. elaborado no inicio da sua investigação.

Geografia Ensino \& Pesquisa, v. 18, n.2, p. $57-76$, maio/ago. 2014

A pesquisa no ensino de Geografia como possibilidade de diálogos trans e interdisciplinares

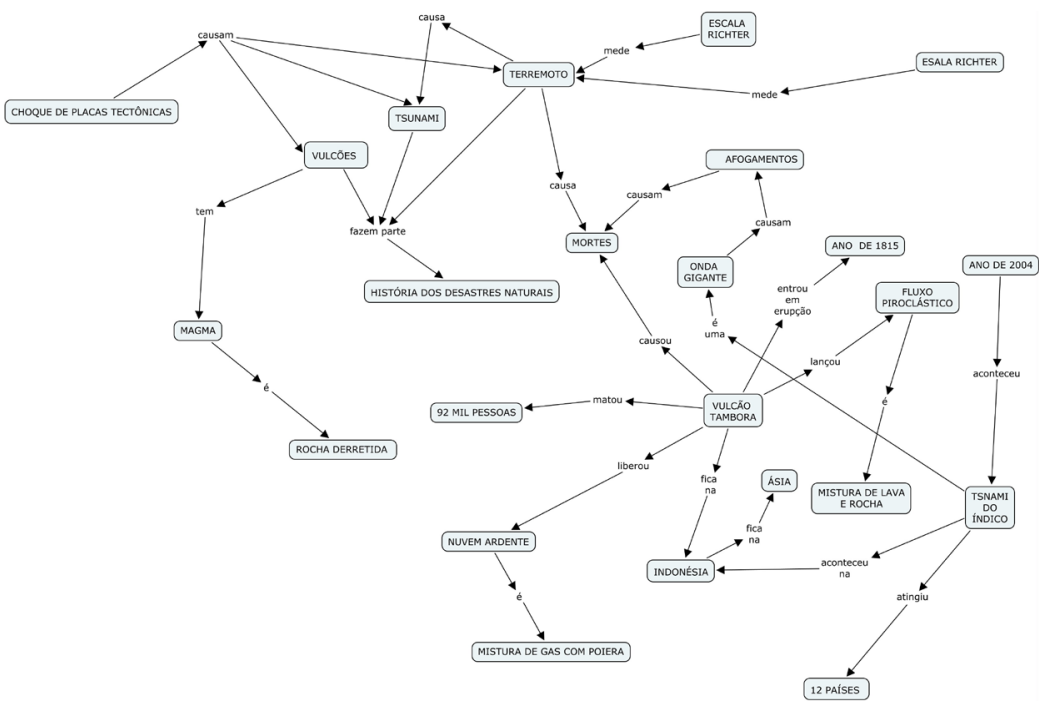

Fonte: arquivo pessoal das autoras. 
Os dois exemplos demonstram que ao pesquisar o aluno ampliou seus conhecimentos, promoveu tecituras mais complexas e aprendeu pesquisando, analisando, interpretando, sintetizando como demonstram os mapas mentais elaborados.

A oficina

A oficina proposta visou uma articulação entre Geografia e Educação Ambiental visando à construção, com os alunos do conceito de ambiente. Buscou-se na metodologia da pesquisa-ação um ensino que apresente dinâmica capaz de produzir um aprendizado relacionado à temática ambiental, tomando como referência o conceito geográfico de lugar. Com base no relatório elaborado pela aluna em atividade de pesquisa/extensão Pâmela Kornalewski da Silva (SILVA, 2008).

\section{Os objetivos desta atividade conforme constam do relatório acima referido são:}

- Desenvolver, implementar e avaliar processos que potencializem a implantação da educação ambiental no ensino formal, considerando sua dimensão ética, política, científica e pedagógica.

- Promover a integração de práticas de diferentes atores - professores, alunos e comunidade - tendo como espaço geográfico a escola e como tema a educação ambiental;

- Potencializar a participação da comunidade escolar na construção do pensamento/ação ambiental através de atitudes responsáveis e comprometidas com questões locais e globais;

- Experienciar diferentes metodologias em relação à educação ambiental;

- Construir com os alunos a compreensão dos conceitos ambiente, lugar e educação ambiental, através de suas vivências e saberes cotidianos e das práticas desenvolvidas durante as ações nas escolas;

- Problematizar as questões ambientais diagnosticadas pela própria comunidade escolar, mas dando uma atenção especial para aquelas questões levantas pelos próprios alunos, nos lugares de enfoque do projeto (Bairros);

A proposta de oficina foi desenvolvida na turma mista de quinta e sexta série que no Colégio de Aplicação corresponde ao Amora I e Amora II, num total de 13 alunos, os temas abordados durante as oficinas centraram-se nos espaços de vivência do aluno - o lugar: CASA, BAIRRO buscando-se a partir daí a construção do conceito de AMBIENTE.

As atividades construídas estão sintetizadas nas seguintes etapas:

\section{- Primeira etapa}

Escolha, sensibilização junto à escola e organização do cronograma de atividades que foram desenvolvidas nas oficinas. A escola escolhida para a parceria nessa atividade foi o colégio de Aplicação - CAP/ UFRGS, no âmbito do projeto Amora. Sendo acordado que a atividade proposta seria sob a forma de oficinas, com a supervisão das professoras das áreas de Geografia e Ciências.

\section{- Segunda etapa}

Seleção das turmas do ensino fundamental que participariam das atividades.

\section{- Terceira etapa}

Organização de material visual para apresentação da proposta à comunidade escolar. Consta esta etapa de uma apresentação aos alunos das oficinas a serem desenvolvidas. Assim, através de uma exposição oral e algumas dinâmicas foi possível levar o entendimento necessário à comunidade escolar da proposta sugerida.

\section{- Quarta etapa}

Processo de escolha pelos próprios alunos da oficina que desejariam participar com base nas referências expostas na etapa anterior.

\section{- Quinta Etapa}

Geografia Ensino \& Pesquisa, v. 18, n.2, p. 57-76, maio/ago. 2014.

Rossato, M. S.; Suertegaray, D. M. A. 
etapa envolveu a seleção de temas e produção de materiais para a instrumentação das práticas na pesquisa. Como produto final optou-se pela construção de uma maquete do bairro. Esta foi produzida individual ou em grupo de alunos. Nesta maquete os alunos apresentariam uma leitura do bairro sob a perspectiva ambiental, destacando aspectos positivos e negativos em suas avaliações.

\section{- Sexta etapa}

Desenvolvimento de oficinas durante os seis meses de atividades práticas num total de 16 encontros.

\section{- Sétima etapa}

Análise dos produtos elaborados pelos alunos durante os encontros interpretação e construção pelos alunos do conceito de ambiente. Relato junto à comunidade escolar envolvida dos resultados alcançados. O Quadro 1 revela a sequência de atividades e procedimentos para a construção da proposta.

A finalização da oficina teve como objetivo a construção com os alunos de uma análise e reflexão sobre as maquetes construídas relacionando-a com os questionamentos abordados durante o desenrolar da oficina. Das perguntas norteadoras da discussão destacamos aqui aquela que solicitava aos alunos sua expressão escrita sobre ambiente. O quadro abaixo revela as diferentes concepções construídas. Desta atividade resultou, por conseguinte, a elaboração da noção/conceito de ambiente e o entendimento de educação ambiental pelos alunos.

Quadro 1-Sequência de atividades e procedimentos para a construção da proposta.

Geografia Ensino \& Pesquisa, v. 18, n.2, p. 57-76, maio/ago. 2014.

A pesquisa no ensino de Geografia como possibilidade de diálogos trans e interdisciplinares

\begin{tabular}{|c|c|c|}
\hline OFICINAS & ATIVIDADES & MATERIAIS NECESSÁRIOS \\
\hline $\begin{array}{l}\text { 09/04 - Apresentação e } \\
\text { conhecimento de mapas }\end{array}$ & $\begin{array}{l}\text { - Dinâmica de apresentação; } \\
\text { - Brincando com a localização dos bairros. }\end{array}$ & $\begin{array}{l}\text { - Cartaz de papel pardo contendo informações } \\
\text { gerais sobre os alunos; } \\
\text { - Mapa dos bairros de POA e Viamão. }\end{array}$ \\
\hline $\begin{array}{l}\text { 16/04 - Mapa mental } \\
\text { CAP/ bairro (alunos) }\end{array}$ & $\begin{array}{l}\text { Mapa mental e solicitação da entrega do mapa } \\
\text { mental }\end{array}$ & $\begin{array}{l}\text { - Folha A3; } \\
\text { - Lápis de cor; } \\
\text { - Lápis; }\end{array}$ \\
\hline 23/04 - Mapa mental & $\begin{array}{l}\text { - Apresentação do mapa mental; } \\
\text { - Análise e descrição de pontos positivos e } \\
\text { negativos do trajeto (discussão em grupo). }\end{array}$ & - Mapa dos bairros de POA e Viamão. \\
\hline $\begin{array}{l}\text { 30/04 - Projeto do Meu } \\
\text { Bairro (trabalho } \\
\text { individual). }\end{array}$ & $\begin{array}{l}\text { - Elaborar o projeto com desenho e colagem; } \\
\text { - Elaborar redação. }\end{array}$ & $\begin{array}{l}\text {-Folha de papel pardo; } \\
\text {-Figuras (da Internet, jornal, revistas, revistas } \\
\text { em quadrinho...); } \\
\text {-Cola; } \\
\text {-Tesoura; } \\
\text {-Lápis de cor ou de cera; }\end{array}$ \\
\hline $\begin{array}{l}07 / 05 \text { - Observando o } \\
\text { ambiente escolar }\end{array}$ & $\begin{array}{l}\text { - Saída de campo no pátio da escola e em } \\
\text { alguns setores do CAP: } \\
\text { - Exercício de comparação entre o ambiente do } \\
\text { bairro e o do colégio. }\end{array}$ & - Bloco de anotações. \\
\hline $\begin{array}{l}\text { 14/05 - Você conhece o } \\
\text { seu meio ambiente? }\end{array}$ & $\begin{array}{l}\text { - Leitura e discussão do texto: Você conhece } \\
\text { seu meio ambiente? (autora: Heloísa Penteado); } \\
\text { - Realização de dinâmica. }\end{array}$ & - Cópia de texto. \\
\hline $\begin{array}{l}21 / 05 \text { - Observação e } \\
\text { relação com texto lido }\end{array}$ & $\begin{array}{l}\text { - Em grupos, trabalho de relação com o que foi } \\
\text { visto nos ambientes do colégio e o texto. }\end{array}$ & - Cópia do texto. \\
\hline $28 / 05$ - Tintas naturais & $\begin{array}{l}\text { - Fabricação de tintas naturais/elementos } \\
\text { verificados no ambiente escolar (exemplo } \\
\text { refeitório e horta). }\end{array}$ & $\begin{array}{l}\text { Tomate, beterraba, terra, bulbo da beterraba, } \\
\text { casca de ovos e uvas, giz, pó de café usado, } \\
\text { liquidificador, }\end{array}$ \\
\hline $04 / 06$ - Tintas naturais & $\begin{array}{l}\text { - Utilização das tintas para pintar o projeto; } \\
\text { - Organização dos grupos para construção das } \\
\text { maquetes por afinidade de projeto; } \\
\text { - Organização dos materiais recicláveis trazido } \\
\text { pelos alunos. }\end{array}$ & $\begin{array}{l}\text { - Projeto; } \\
\text { - Tintas naturais (prontas) }\end{array}$ \\
\hline $\begin{array}{l}11 / 06 \text { - Maquete e tintas } \\
\text { naturais }\end{array}$ & $\begin{array}{l}\text { - Utilização das tintas naturais para colorir as } \\
\text { maquetes }\end{array}$ & $\begin{array}{l}\text { - Tintas naturais; } \\
\text { - Materiais recicláveis. }\end{array}$ \\
\hline 18/06 - Maquete & - Construção das maquetes. & - Matérias recicláveis. \\
\hline 25/06 - Maquete & - Construção das maquetes. & - Materiais recicláveis. \\
\hline 02/07-Maquete & - Construção das maquetes. & - Matérias recicláveis. \\
\hline $\begin{array}{l}09 / 07 \text { - Estudo final sobre } \\
\text { as maquetes }\end{array}$ & $\begin{array}{l}\text { - Atividade de análise das maquetes, } \\
\text { questionário a ser respondido pelo grupo }\end{array}$ & - Maquetes. \\
\hline 16/07 - Ensaio final & - Ensaio final para apresentação das maquetes & - Maquetes. \\
\hline 04/08 - Apresentação final & $\begin{array}{l}\text { - Apresentação e trocas de experiências com as } \\
\text { outras oficinas que foram desenvolvidas no } \\
\text { mesmo período. }\end{array}$ & - Maquetes. \\
\hline
\end{tabular}

Fonte: elaborado pelas autoras. 
"Antigamente, nós achávamos que o ambiente era a natureza, mas depois das oficinas descobrimos que o ambiente é aonde nós vivemos. E é importante discutir este tema para poder saber como arrumar e cuidar dos ambientes que estudamos." (alunos C. O. e G. E.).

"Ambiente é a relação dos elementos da natureza com o meio urbano, quase tudo ou tudo que se tem no meio urbano depende da natureza. Em fim, é a natureza transformada." (aluna G. M.)

"Para nós ambiente é onde vivemos e o que devemos preservar. A importância de discutir os problemas do nosso bairro é para tentarmos fazer com que as pessoas pensem antes de tocar lixo, poluir e desmatar." (alunas A. A. e C. P.)

"Aprendi que ambiente não é só natureza, mas é tudo a nossa volta. É quem cuida da natureza modificada. E também quem ensina sobre natureza - professora da oficina." (aluno C. O.)

"É as pessoas (nós) preservando a natureza, mesmo nas áreas urbanas que é uma natureza transformada." (aluna J. M.)

"Educação ambiental é o que devemos ter e fazer para cuidar do nosso ambiente." (aluna A. A.)

"Eu aprendi que tudo tem um segundo uso, ou seja, que podemos reciclar os mesmos e que mesmo assim podemos fazer coisas legais (como a nossa maquete)." (aluno E. W.).

Os conceitos são reveladores do processo de construção de conhecimento, inovam na percepção ambiental e demonstram sínteses interpretativas do que aprenderam.

\section{Reflexões sobre a prática}

O trabalho através de projetos de aprendizagem tem como ponto de partida as curiosidades individuais, parte, portanto, do interesse pessoal de cada criança. Este desejo de descobertas pode ser sobre as mais diversas temáticas, entretanto de alguma forma estão inseridas no seu cotidiano, nas suas vivências. Isto se revela, na maior parte das vezes, como um importante motivador da aprendizagem, pois interessado em desvendar seu objeto de pesquisa, o aluno dedica-se ao trabalho de forma mais persistente, aceita os desafios propostos e sente-se valorizado enquanto autor de um trabalho.

As oficinas no contexto do projeto Amora, são complementares permitem ao aluno a escolha e o aprofundamento de um tema e habilidades de pensamento como a que foi aqui apresentada, através desta prática buscou-se a construção de um conceito, o de ambiente. Para tanto, partiu-se da proposta de construção, pelo conjunto dos alunos, de uma maquete que revelasse a problemática ambiental.

As duas práticas buscam a construção do conhecimento a partir do interesse e da curiosidade do aluno. A experiência de Projeto, como foi aqui demonstrada, é reveladora de uma atitude que exige curiosidade, concentração, persistência além da capacidade de vencer desafios privilegiando o trabalho individual. A segunda prática relatada - a oficina - da mesma forma estimula a curiosidade, a criatividade e os desafios, neste caso a partir de uma experiência coletiva, considerando que as maquetes foram resultado de uma construção conjunta. Por outro lado a reflexão sobre o produto do trabalho gerou construções conceituais distintas na construção verbal, mas reveladora de um mesmo conteúdo.

Metodologicamente se diferenciam, pelo estímulo ao trabalho individual e ao trabalho coletivo e pelas formas de divulgação dos resultados. Em termos de interação professor - professor, professor - aluno e aluno-aluno são práticas complementares que, como foi dito inicialmente fazem parte do projeto Amora, mais amplamente.

A necessidade do diálogo com colegas e professores, desperta-o para o trabalho cooperativo e colaborativo. Muitas vezes notamos mudança de comportamento da criança em sala se aula, seja no que se refere aos aspectos de relacionamento, como melhora na auto-estima e autoconfiança, seja nos aspectos organizacionais, como o cuidado maior para com seus materiais

Geografia Ensino \& Pesquisa, v. 18, n.2, p. 57-76, maio/ago. 2014.

Rossato, M. S.; Suertegaray, D. M. A. 
e dos colegas e maior responsabilidade nas entregas dos trabalhos.

Sobre a significação e motivação para o estudo, Freire (1975) diz que:

\begin{abstract}
estudar é, realmente, um trabalho difícil, que exige disciplina intelectual que não se ganha senão praticando, dá ao trabalho (ato de estudar) a significação lúdica, pois ninguém realiza uma atividade séria, penosa, se não tivesse o mínimo de satisfação e predisposição para isso.
\end{abstract}

A curiosidade inquieta os educandos, faz suscitar perguntas, dúvidas, idéias. É a partir da curiosidade que emerge criatividade. “(...) Não haveria criatividade sem a curiosidade que nos move e que nos põem pacientemente impacientes diante do mundo que não fizemos, acrescentando a ele algo que fazemos" (FREIRE, 1997) Esta criatividade, segundo Paulo Freire, estimula a busca por coisas novas, por novos temas, por novas experiências e enriquece o processo educacional.

Esta busca vivenciada no ato de pesquisar revela um processo que o ensino disciplinar raras vezes contempla, ou seja, a possibilidade de vivência da transdisciplinaridade, enquanto transito, pois, o ato de responder uma questão exige conhecimento ampliado e percursos variados, exige um colocar-se no lugar de, reconhecendo que as respostas aos problemas formulados vão além da disciplina. Este transito por sua vez promove conexões instalando-se a interdisciplinaridade na prática revelada pela ação conjunto de diferentes professores envolvidos na resolução de um problema.

No que se refere à Geografia constante busca de inovações e informações, pelo professor de Geografia, é fundamental num mundo globalizado e altamente interconectado, e onde as transformações ganham dimensões extraterritoriais. A inovação busca melhorar, ampliar, mudar antigas práticas para poder construir com o aluno o conhecimento, valendo-se das novas tecnologias e recursos para a facilitação da aprendizagem.

Maturana (1994, p. 26), médico e biólogo chileno, juntamente com Varella, conceituam educação dizendo:

\footnotetext{
Educar é um processo no qual a criança ou o adulto convive com o outro e ao conviver se transforma espontaneamente, de maneira que seu modo de viver se faz progressivamente, mais congruente com o do outro no espaço de convivência. O educar ocorre, portanto, todo o tempo, de maneira recíproca como uma transformação estrutural contingente a uma história no conviver que resulta que as pessoas aprendem a viver de uma maneira que se configura segundo o conviver da comunidade aonde vivem.
}

Geografia Ensino \& Pesquisa, v. 18, n.2, p. $57-76$, maio/ago. 2014.

A pesquisa no ensino de Geografia como possibilidade de diálogos trans e interdisciplinares

Atualmente fala-se da importância de promover o ensino a partir da vivência, em geral proposto, na Geografia, como centrado no lugar (enquanto espaço próximo). Entretanto, a prática aqui revelada indica que a concepção de lugar enquanto espaço próximo não, necessariamente, é condição absoluta para uma proposição educativa A prática de projeto revelou questões de perspectiva vivencial mais ampla, interesses de âmbito espacial mais longínquo. Revelando-se essa prática como possibilidade pertinente para a realização de uma reflexão sobre o lugar na Geografia - a partir de quem?

O que motiva uma criança para aprender tem sido o constante interesse de psicólogos educadores nos últimos anos. A identificação dos possíveis componentes da motivação, como por exemplo, o intrínseco interesse da criança em aprender, a curiosidade, a preferência ou não por atividades desafiadoras, a necessidade de aprovação ou não por parte dos professores, a dependência ou não da orientação do professor, bem como a dependência das notas é de extremamente relevância no contexto específico de sala de aula. Identificar estes componentes permite ao professor organizar e/ou criar estratégias o propiciem um maior engajamento do aluno com seu próprio processo de construção do conhecimento.

Tomando esta experiência, é significativo pensarmos o papel do ensino- pesquisa neste 
processo. Continuando com Maturana (1994, p. 26), na sua percepção da educação, temos:

Toda a história individual é a transformação de uma estrutura inicial hominídia fundadora de maneira contingente em uma história particular de interações que se dá constitutivamente no espaço humano, que se constitui na história hominídia a qual pertencemos com o estabelecimento da linguagem como parte de nosso viver".Em outras palavras, "como vivemos, educaremos, e conservaremos no viver o mundo, que vivemos como educandos. E educamos ao outro com nosso viver com eles, o mundo que vivemos no conviver.

Enfim, o que desejamos com este texto é apresentar possibilidades de ensino que associado-se a investigação e vindo ao encontro do interesse do aluno torna o ato de ensinar-aprender certamente, mais relevante.

\section{Referências}

BRASIL, SECRETARIA DE EDUCAÇÃO FUNDAMENTAL. Parâmetros Curriculares Nacionais

- Geografia. Brasília: MEC/SEF, 1998. 156p.

CASTROgIOVANNI, A.; ROSSATO, M. S.; CÂMARA, M. A.; SILVA, R. R. Ensino de Geografia: caminhos e encantos. Porto Alegre: Editora PUCRS, 2007. 148p.

CARR, W; KEMMIS, S. Teoria critica de la enseñanza. Barcelona: Ediciones Martinez Roca, 1988.

ESTRÁZUlas, M. B. P. GOULART, L. B. (Organizadoras) Projeto Amora - Relatório bi-anual 19971998.

DUTRA, I. M.; CAMARGO, F. B.; VALENTINI, N. C.; MIGNONI, R. P. L.; MERG, Y. M. G. Projeto Amora 2000. 1999. 29p.

FREIRE, P. Pedagogia do Oprimido. Edições Afrontamento, 1975.

FREIRE, P. Pedagogia da Autonomia - Saberes necessários à prática educativa. São Paulo: Paz e Terra, 1997.

GARDNER, H. Inteligências Múltiplas: a teoria na prática. Porto Alegre: Artes Médicas, 1995.

HERNÁNDEZ, F.; VENTURA, M. A organização do currículo por projetos de trabalho. Porto Alegre: Artes Médicas, 1998.

INSTITUTO PAULO FREIRE. Inter-transdisciplinaridade e tranversalidade. Programa de Educação Continuada. Projetos e Textos. Acesso em 19 de março de 2009. Disponível em: http://www.inclusao. com.br/projeto_textos_48.htm

Geografia Ensino \& Pesquisa, v. 18, n.2, p. 57-76, maio/ago. 2014.

Rossato, M. S.; Suertegaray, D. M. A.

ISSN 2236-4994 
MORIN , E . Introdução ao Pensamento Complexo. 2 Edição. São Paulo: Instituto Piaget, 1990.

PIAGET, J. Problemas gerais da investigação interdisciplinar e mecanismos comuns. Lisboa: Ed. Bertrand, 1973.

ROSSI, D. R.; ROSSATO, M. S. Geografia (em)canto. In: Encontro Estadual de Geografia, 27, 2007, Santa Maria. Anais do XXVII Encontro Estadual de Geografia AGB/Porto Alegre: Santa Maria, 2007.

SANTOMÉ, J. T. Globalização e interdisciplinaridade: o currículo integrado. Porto Alegre: Artes Médicas, 1998.

SERRANO, M. da G. P. Investigación- acción; aplicaciones al campo social y educativo. Madrid: Dykinson, 1990 .

SILVA P. K. da Educação Ambiental: Vivências no Urbano. Relatório Final da bolsa BIC/FAPERGS. Orientadora profa. Dra. Dirce Maria Antunes Suertegaray. Porto Alegre, 2008. Inédito

SUERTEGARAY, D. M. A. Pesquisa e Educação de professores. In: PONTUSCHKA, N. N.; OLIVEIRA, A. U. Geografia em perspectiva. São Paulo: Editora Contexto, 2002. P. 119-114.

SUERTEGARAY, D. M. A. Geografia e Interdisciplinaridade. Espaço geográfico: interface natureza e sociedade. Geosul, Florianópolis, v. 18, UFSC, p. 43 - 54, 2003.

VIGOTSKY, L. A formação social da mente. São Paulo: Martins Fontes, 1984.

\section{Correspondência:}

\section{Maíra Suertegaray Rossato}

E-mail: msuerte@terra.com.br

Recebido em 17 de agosto de 2013.

Aceito para publicação em 24 de agosto de 2014.

Geografia Ensino \& Pesquisa, v. 18, n.2, p. 57-76, maio/ago. 2014

A pesquisa no ensino de Geografia como possibilidade de diálogos trans e interdisciplinares 